Summer 1991

\title{
Hannah Arendt, National Socialism and the Project of Foundation
}

Robert Mayer

Loyola University Chicago, rmayer@luc.edu

Follow this and additional works at: https://ecommons.luc.edu/politicalscience_facpubs

Part of the Political Science Commons

\section{Recommended Citation}

Robert Mayer (1991). Hannah Arendt, National Socialism and the Project of Foundation. The Review of Politics, 53, pp 469-487. doi:10.1017/S0034670500015254.

This Article is brought to you for free and open access by the Faculty Publications and Other Works by Department at Loyola eCommons. It has been accepted for inclusion in Political Science: Faculty Publications and Other Works by an authorized administrator of Loyola eCommons. For more information, please contact ecommons@luc.edu.

\section{(c) (1) $\Theta$}

This work is licensed under a Creative Commons Attribution-Noncommercial-No Derivative Works 3.0 License. (c) University of Notre Dame, 1991. 
Hannah Arendt, National Socialism and the Project of Foundation

Author(s): Robert Mayer

Source: The Review of Politics, Vol. 53, No. 3 (Summer, 1991), pp. 469-487

Published by: Cambridge University Press for the University of Notre Dame du lac on behalf of Review of Politics

Stable URL: http://www.jstor.org/stable/1407859

Accessed: 13-05-2015 18:11 UTC

\section{REFERENCES}

Linked references are available on JSTOR for this article:

http://www.jstor.org/stable/1407859?seq=1\&cid=pdf-reference\#references_tab_contents

You may need to $\log$ in to JSTOR to access the linked references.

Your use of the JSTOR archive indicates your acceptance of the Terms \& Conditions of Use, available at http://www.jstor.org/page/ info/about/policies/terms.jsp

JSTOR is a not-for-profit service that helps scholars, researchers, and students discover, use, and build upon a wide range of content in a trusted digital archive. We use information technology and tools to increase productivity and facilitate new forms of scholarship. For more information about JSTOR, please contact support@jstor.org. 


\section{Hannah Arendt, National Socialism and the Projeet of Foundation}

\section{Robert Mayer}

Foundation is a crucial concept in Hannah Arendt's work. She was especially interested in modern attempts, successful and unsuccessful, to found new bodies politic. Arendt maintained, however, that totalitarian movements were hostile to the project of foundation. Far from seeking to stabilize the world, totalitarianism set the world in motion and tried to keep it moving. But when we turn to National Socialist ideology itself we discover that foundation was vital to the Nazi project; Hitler understood himself as the founder of his people. Arendt's own interpretation of Nazism is mistaken, but I believe that her general theory of foundation can help us to make sense of the National Socialist experience. This article examines the project of foundation in Hitler's Weltanschauung and redeploys Arendt's concepts to explain his unsuccessful attempt to create a new body politic.

Although Hannah Arendt described German National Socialism as "totalitarian," she did not think that a longing for total power or monolithism per se were the decisive traits of this "novel form of government." Rather, what distinguished totalitarianism from all other types of regimes was that it generated and thrived on impermanence. Traditionally governments and laws had been "designed to function as stabilizing factors for the ever-changing movements of men," but in the totalitarian party-state, Arendt claimed, "the essence of government itself has become motion." Totalitarian regimes are driven by a kind of "perpetual-motion mania" and "can remain in power only so long as they keep moving and set everything around them in motion." They do not attempt to construct a durable world to protect individuals from the flux of nature and the unpredictability of action but seek instead "to set into motion a body politic" and "to keep the movement in constant motion." They use terror and coercion on an unprecedented scale to demolish the stabilizing structures of the world and plunge individuals into an endless historical "process."

It was for this reason that Arendt denied that the National Socialist regime was "authoritarian," for according to Arendt the essential feature of authoritarian government is permanence and

1. Hannah Arendt, The Origins of Totalitarianism (New York: Harcourt Brace Jovanovich, 1973), pp. 463, 466. Arendt also said that "terror is the essence of totalitarian domination" (p. 464), but terror was used as a means to accelerate the motion on which totalitarianism thrived.

2. Ibid., pp. 306, 467-68. 
continuity. Authoritarian regimes are tied back to a foundation, which they seek to preserve and renew in changing circumstances. ${ }^{3}$ Totalitarian movements, on the other hand, reject the attempt to construct and preserve a durable foundation and seek instead to cut society loose from its traditional moorings so that it may flow with the inexorable forces of history or nature. In place of law as "the stabilizing source of authority for the actions of mortal men" they substitute the laws of nature or history, which are "laws of movement." Thus the higher law no longer serves to anchor the body politic but makes all permanence and stability impossible, and thereby prepares the way for "the transformation of human nature itself" in accordance with an ideology. ${ }^{4}$ Totalitarian regimes feed upon and intensify the "rootlessness" and "homelessness" generated by the rise of what Arendt called "world alienation" in order to fabricate an entirely new humanity devoid of the potential for action.

This interpretation of totalitarianism, however, contradicts the claims of the National Socialist movement itself. While Arendt explored the concept of foundation and the politics of stability and motion more carefully than any other contemporary theorist, she failed to see that foundation was central to the National Socialist project and to Hitler's Weltanschauung. National Socialism arose in opposition to the forces of movement unleashed in the modern age, and it claimed to preserve the Volk from decay by returning to the original foundation of the German people. Indeed, Hitler understood himself to be a founder or refounder, and he declared that "our true object is to set up our rule for all time, and to anchor it so firmly that it will stand firm for a thousand years." The perversity of National Socialism, I believe, lay not in a rejection of foundation and a desire for endless motion as such, but rather in the peculiar character of its project of foundation. It was the National Socialist attempt to create stability, not to set the world in motion, that led to the German catastrophe.

In this article I explore the curious project of foundation in Hitler's Weltanschauung through Arendtian categories. My aim here is not so much to refute Arendt but to redeploy her concepts to help

3. Hannah Arendt, "What Is Authority?" in Between Past and Future (New York: Penguin, 1968), pp. 91-141.

4. Arendt, Origins, pp. 463, 458-59.

5. Quoted in Hermann Rauschning, The Voice of Destruction (New York: Putnam, 1940), p. 39. 
make sense of the National Socialist experience ${ }^{6}$ While Arendt's own interpretation of National Socialism is flawed, her analysis of the project of foundation can help us to understand the Nazi movement and its recourse to coercion and genocide. National Socialism, I will argue, is the clearest instance of the tendency Arendt noted in the modern age to substitute fabrication for action when laying the foundations of a body politic.

The article is divided into three parts. The first explains Arendt's concept of foundation; the second explores the National Socialist project of foundation as expressed in Hitler's works; in the final part I use Arendt's theory to analyze Hitler's founding and his attempt to stabilize a world in motion.

Hannah Arendt both praised and feared motion in political affairs. She praised it because action is movement. To act is "to take an initiative, to begin ... to set something into motion." Those who act insert themselves into the world and begin a new line of direction. Rooted in natality, action is a kind of second birth, "the spontaneous beginning of something new" through which we disclose ourselves and manifest our freedom as undetermined beings. ${ }^{7}$ Motion in the form of action is therefore a vital part of the human condition.

Yet Arendt also feared motion unchecked by a durable world. Action by its very nature is boundless and unpredictable, and it therefore needs "a framework that can reliably withstand the onslaught with which each new generation must insert itself." Boundaries, fences, and laws "are of such great importance to the stability of human affairs precisely because no such limiting and protecting principles rise out of the activities going on in the realm of human affairs itself." ${ }^{8}$ Action by itself can leave no trace or win the immortality it seeks; indeed, its tendency as a "new beginning"

6. My aim is significantly different from Stephen Whitfield's in Into the Dark: Hannah Arendt and Totalitarianism (Philadelphia: Temple University Press, 1980). While Whitfield examines Arendt's empirical account of totalitarianism in light of recent historical studies, I am only interested in the adequacy of her philosophical interpretation of National Socialism.

7. Hannah Arendt, The Human Condition (Chicago: University of Chicago Press, 1958), pp. 177, 234.

8. Ibid., p. 191. 
is to wipe away the memory of past deeds. Without the "stabilizing protection" of "the walls of the polis and the boundaries of the law," the public space in which individuals show themselves "could not endure, could not survive the moment of action and speech itself." The human condition would dissolve into the eternal and anonymous cycle of birth and death that characterizes mere nature without a secure and enclosed space in which to act.

But "if the world is to contain a public space, it cannot be erected for one generation and planned for the living only; it must transcend the life-span of mortal men." ${ }^{10}$ This is the task of foundation - to establish a framework of laws and institutions that will serve as a bulwark against the forces of motion inherent in nature and in action and create a stable space of appearance. The foundation constitutes the body politic, and for this reason Arendt warned that it should not be thought of as a product of the will of its members, for the "will of a multitude ... is ever-changing by definition ... and a structure built on it as its foundation is built on quicksand." "The will is "the spring of action," but "the 'lawless' freedom the will seems to enjoy" would undercut the permanence of any boundaries it established. ${ }^{12}$ A constitution which is merely an expression of the popular will may be changed at will and could not therefore serve as the foundation for an enduring structure. Thus, the constitution must be viewed as a higher law or absolute which stands above the will of the people, binding the community to a fixed point and anchoring it against the forces of change and motion.

Arendt described two distinct models of foundation, one associated with the Greeks and the other with the Romans. In the Greek poleis the foundation was considered a product of fabrication and not of political action itself. The founder or lawgiver was a "craftsman or architect," "the builder of the city wall, someone who had to do and finish his work before political activity could begin."13 The advantage of this model was that action and the popular will

9. Ibid., p. 198. For a good account of motion and stability in Arendt's thought see Leroy Cooper, "Hannah Arendt's Political Philosophy: An Interpretation," Review of Politics 38 (1976): 161-71.

10. Arendt, Human Condition, p. 55.

11. Hannah Arendt, On Revolution (New York: Penguin, 1977), p. 163. Arendt attributed the calamities of the French Revolution to the failure to find an absolute above the popular will.

12. Hannah Arendt, The Life of the Mind, 2 vols. (New York: Harcourt Brace Jovanovich, 1978), 2: 6, 27.

13. Arendt, Human Condition, pp. 194-195. 
were disconnected from constitution-making and made dependent on it. Action went on inside the structure laid by the founder but did not concern itself with the building as such.

In the Roman republic, on the other hand, foundation was not viewed as fabrication but as action itself, the beginning of a new story. The new beginning, however, escaped the boundlessness and mutability inherent in action by becoming authoritative to all succeeding generations. The Romans treated this first action of constituting the city as "the central, decisive, unrepeatable beginning of their whole history, a unique event."

At the heart of Roman politics, from the beginning of the republic until virtually the end of the imperial era, stands the conviction of the sacredness of foundation, in the sense that once something has been founded it remains binding for all future generations. To be engaged in politics meant first and foremost to preserve the founding of the city of Rome. ${ }^{15}$

The first action of founding the city was considered constitutive of all later action so that each new generation was bound to the initial project and had to act within the parameters established by the founders. The beginning became the source of authority or the absolute for succeeding generations, which remained tied back to the constitution of the ancestors despite changing circumstances. Their task was to renew the founding in each generation and pass it on uncorrupted to the newcomers who would enter the world after them.

Arendt favored the Roman model of foundation because it created a sturdier structure to withstand the forces of motion without however abolishing the space for action. The Greek model was serviceable enough, but it lacked the principle of authority fundamental to the stability of the Roman foundation and it "did not command the same loyalty we know from the Roman type of patriotism. ${ }^{" 16}$ A work of fabrication can be altered or discarded if it loses its utility, but the action or beginning which has given one life will always be reverenced. What is more, Arendt believed that the image of founding as fabrication held a great danger, for fabrication can become a substitute for action itself and abolish the public

14. Arendt, "What Is Authority?" p. 121, and in general pp. 120-28.

15. Ibid., p. 120.

16. Arendt, Human Condition, p. 195. 
space it ought to create. Plato, for instance, because he feared the unpredictable character of democratic action, tried "to substitute making for acting in order to bestow upon the realm of human affairs the solidity inherent in work and fabrication." "It is as though [he] had said that if men only renounce their capacity for action, with its futility, boundlessness and uncertainty, there could be a remedy for the frailty of human affairs." ${ }^{17}$ Stability here is won at the expense of action, and such an effort is all too likely to devolve into despotism as the violence inherent in fabrication is turned against the members themselves in order to prevent them from acting or moving spontaneously. The founder as fabricator is apt to use individuals as means to an end and to treat them as stones to be hewn and fitted into an immovable structure that leaves no space for action.

Totalitarianism differs from despotism, however, because it does not seek to stabilize the world but to set it into motion, and it therefore is opposed to the attempt to lay foundations. Totalitarian government rejects the notion that any laws, constitutions or authoritative principles can restrict its power or that it is tied back to a founding in the past. ${ }^{18}$ Its goal is to abolish all action and even human spontaneity itself by eliminating the stability and solidity of a world. Totalitarianism only developed "against a background of a more or less general, more or less dramatic breakdown of all traditional authorities," and it merely sought to intensify the "world alienation" which preceded it and made it possible. ${ }^{19}$

True enough, National Socialism claimed to obey and defend certain laws - the higher laws of nature - but Arendt argued that for the Nazis "the term 'law' itself changed its meaning: from expressing the framework of stability within which human actions and motions can take place, it became the expression of motion itself." The National Socialists tried to realize "Darwin's idea of man as the product of a natural development which does not necessarily stop with the present species of human beings." By accelerating the laws of natural selection and allowing them "to race freely through mankind" the Nazi regime cast uprooted masses into the evolutionary flow of nature without the protection of a durable world..$^{20}$ They consciously destroyed all fixed points so that the

17. Ibid., pp. 225, 195. See also Arendt, "What Is Authority?" pp. 104-20.

18. Arendt, "What Is Authority?" pp. 96-97.

19. Ibid., pp. 91-92.

20. Arendt, Origins, pp. 463-65. 
movement inherent in nature could lead to the evolution of a new and higher man and the extermination of all lower races destined to perish in the eternal struggle for survival. The danger which the Nazis posed was "not that they might establish a permanent world" but that they would "ravage the world as we know it . . . before a new beginning . . . had time to assert itself." ${ }^{21}$

\section{II}

It is true that in the Darwinian schema nature is in constant evolutionary motion. Species are "doomed to an infinite progress without ever reaching any inherent telos or approaching any preordained idea." ${ }^{22}$ With changes in the environment certain characteristics in a species will be favored over others in the struggle for reproductive success and will come to predominate. Since environmental change is continual species are in a constant state of evolution and are never complete; as a part of nature they are always in flux.

Arendt claimed that the National Socialist regime obeyed these Darwinian laws of motion and applied them to human communities. It merely tried to accelerate their action by exterminating "races or individuals who are 'unfit to live." 23 The Jews were said to be a dying race, biologically unfit and destined to perish in the struggle for survival, and the Nazis were therefore executing nature's sentence against them. The victory of the higher Aryan race was said to be inevitable - just as Marx said that the victory of the proletariat was inevitable - and National Socialism therefore freed the evolutionary laws to race through the human condition.

But just as Arendt failed to see the radical difference between Marx and Lenin on the politics of motion and the direction of history, she also failed to see the distinction between Darwinism and National Socialism. ${ }^{24}$ National Socialism was in no meaningful sense applied Darwinism. Hitler did not believe that natural selection had already chosen the Aryans as the fittest race to rule the

21. Ibid., p. 478 .

22. Arendt, Human Condition, p. 307.

23. Arendt, Origins, p. 466.

24. Robert Mayer, "Hannah Arendt, Leninism, and the Disappearance of Authority," Polity (forthcoming). 
planet. ${ }^{25} \mathrm{He}$ never argued that the triumph of the Aryan was historically inevitable or that the Jew was destined to perish. Indeed, Hitler feared the direction history was taking, for he believed that unless it could be stopped the tendency of history would lead to the degeneration and ultimate destruction of the Aryan. For generations the Aryan race had been dissolving into a "racial chaos," and only the intervention of National Socialism, it was hoped, "at the eleventh hour would halt the chariot of doom" (MK 373).

Certainly Hitler believed that the Aryan was culturally superior to all other races. The Aryan was the "culture-founding race," the one responsible for all great works of art in human history (MK 290). But this did not mean that the Aryan was biologically fitter than other races or that the "culture-destroying" Jew was a dying race. On the contrary, Hitler feared that "some day the world will ... come into possession of the culturally inferior but more active men" (MK 135). The Jews, who had survived longer than any other people, were gaining power everywhere and appeared destined for victory:

When over long periods of human history I scrutinized the activity of the Jewish people, suddenly there rose up in me the fearful question whether inscrutable Destiny . . . did not with eternal and immutable resolve, desire the final victory of this little nation (MK 64).

The cultured Aryan had thus far been less ruthless than other races and seemed to lack the will to preserve himself, and thus "more brutal and more natural peoples" threatened him with destruction. What Hitler feared above all was the coming "domination of the inferior being" (MK 135, 320).

National Socialism therefore exterminated the Jews not because they were deemed a dying race, doomed by the law of evolution to perish, but because they were considered "a parasite in the body of other peoples" (MK 304). The Jews were categorized as lebens-

25. References to Hitler's Mein Kampf, trans. R. Manheim (Boston: Houghton Mifflin, 1943), are cited in parentheses (MK followed by page number) in the text of the article. While National Socialist ideology was by no means uniform, I concentrate solely on Hitler's thought because he was the founder and his self-understanding of the Nazi project is crucial. For general surveys of Hitler's thought see Eberhard Jaeckel, Hitler's Weltanschauung, trans. H. Arnold (Middletown: Wesleyan University Press, 1972); Werner Maser, Hitlers Mein Kampf (Munich: Bechtle Verlag, 1966); Joachim Fest, Hitler, trans R. \& C. Winston (New York: Harcourt Brace Jovanovich, 1974), pp. 199-220; Hans Staudinger, The Inner Nazi (Baton Rouge: Louisiana State University Press, 1981). 
unwertes Leben for the same reason that an infectious disease is considered "life unworthy of life." ${ }^{" 26}$ Hitler believed that unless this "noxious bacillus" could be stamped out it "must ultimately result in the collapse of human civilization and the consequent devastation of the world" (MK 64). "If, with the help of his Marxist creed, the Jew is victorious over the other peoples of the world, his crown will be the funeral wreath of humanity and this planet will, as it did thousands of years ago, move through the ether devoid of men" (MK 65).

National Socialism understood itself as an attempt to intervene in the movement of history and reverse its direction. ${ }^{27}$ It sought to halt the otherwise inevitable degeneration of the Volk through "a national awakening of the German people." If left to itself the Aryan race would surely succumb to the "stronger enemy" because "our people's will for self-preservation vanished" (MK 327, 329). Hitler insisted that the Aryan people had lost the will or instinct to preserve itself and that only the National Socialist movement and its Weltanschauung could secure the "recovery of the inner unity of our people's will" (MK 334).

This is a curiously un-Darwinian concept. In evolutionary theory life always has an "instinct" to preserve itself and pass on its genes. A species cannot lose this instinct or "forget" to struggle for its existence. And obviously the German people had not lost the basic biological drive to reproduce themselves. Hitler's point, rather, was that the Germans had lost their racial awareness and the will to preserve themselves as a race. Individuals continued to struggle and to reproduce themselves, but they had lost their racial identity and mixed their Aryan blood with other races, thereby defiling that blood and destroying the race. Individuals may survive in the resulting offspring, but the race itself will be lost in a chaos of alien peoples and become extinct. Hitler claimed that leaving such vital decisions to the will of the individual had already

26. On the concept of "life unworthy of life" and the medical justification for genocide see Robert Jay Lifton, The Nazi Doctors (New York: Basic Books, 1986). See also Alexander Bein, "Der Jüdische Parasit," Vierteljahrshefte für Zeitgeschichte 13 (1965): 121-49.

27. Joachim Fest notes that "What linked Hitler with the leading Fascists of other countries was the resolve to halt this process of degeneration." Anxiety and "fear of the future" characterized the era of fascism. See Fest, Hitler, pp. 101-104. Similarly Ernst Nolte argued that racist thought denied "the value of historical development" because it viewed it as "inescapable degeneration." See Ernst Nolte, Three Faces of Fascism, trans. L. Vennewitz (New York: Mentor, 1965), p. 363. 
resulted in the degeneration of the race and that only guidance by the racially aware could prevent further decay.

The task of National Socialism, then, was to "replace his [the Aryan's] lost instinct by perceptive knowledge; this knowledge must then perform the required work of compensation" (MK 401). Long ago the German people had mixed only with their own kind and had remained racially pure by instinct, but with the corruption of their blood this instinct had faded and now had to be replaced by a "race conscious" movement. Through its Weltanschauung National Socialism "strives to bring the German people to racial awareness" (MK 646). The Nazi party was a kind of a race conscious vanguard of the Volk, a body of the enlightened who would make the people "conscious of its blood" (MK 325)..$^{28}$

"Man can defy the eternal laws of the will to conservation for a certain time, but sooner or later vengeance comes" (MK 132). According to Hitler, the decay of the German people had come about because they had sinned against the higher laws of nature which govern all life. The will of the individual had been the only law acknowledged, but Hitler warned that extinction is the inevitable fate of all those who "forget that they owe their higher existence . . . to the knowledge and ruthless application of Nature's stern and rigid laws" (MK 288). The will must be subordinated to the higher law, for "the right of personal freedom recedes before the duty to preserve the race" (MK 255).

These laws of nature, however, were not laws of motion, as Arendt claimed. Indeed, the supreme law according to Hitler was not a Darwinian law at all. Arendt maintained that the fundamental law for National Socialism was "to eliminate everything that is harmful and unfit to live," and thereby to enforce the law of evolutionary motion. ${ }^{29}$ But in fact this is not the law of nature that National Socialism placed above the will of the people and executed. Instead, its fundamental law demanded the preservation of the race and its blood. This was not a law of motion but a law to prevent motion - the corruption of the blood and the degeneration of the race. For Hitler, "Blood sin and desecration of the race are

28. The influence of Lenin's vanguard party on National Socialism is obvious in Hitler's text. Just as the proletariat could not attain class consciousness without the guidance of the socialist intelligentsia, neither could the Volk achieve racial consciousness without the leadership of the nationalist intelligentsia. Both sought to place the law above the popular will.

29. Arendt, Origins, p. 464. 
the original $\sin$ in this world and the end of a humanity which surrenders to it" (MK 249). The task of National Socialism was to prevent the Aryan from sinning against the law of nature by enforcing blood purity.

According to the Nazis, nature demanded "the inner segregation of the species" (MK 284), the inbreeding of the race and the purification of its blood. But this was in no sense a Darwinian law. Indeed, Darwin taught that variations in a species are good because they allow that species to adapt to changing conditions. A homogeneous population is more likely to perish as the environment changes. In Darwinian theory no particular set of traits is good in itself; it can only be considered "good" if it is chosen by natural selection and leads to reproductive success. Species adapt by changing their traits or perish in the struggle for existence. The National Socialist law of nature, however, was not a law of adaptation but a breeding law. ${ }^{30}$ The Nazis did not believe that the threat to the Aryan race arose from changing environmental conditions that demanded racial evolution and adaptation. On the contrary, their vision of the environment was static. Their task was not to encourage mutation or evolution but to preserve the race from contamination and change; they did not want evolution because then the Aryan would lose the culture-founding traits he already possessed. Hitler drew his higher law not from Darwin but from the field of horticulture and animal breeding. To preserve the characteristics of the greyhound one must keep the breed pure. One must not bastardize it by breeding it with the poodle or other alien "races" for the greyhound will then lose its distinctive traits and degenerate. The National Socialists maintained that the same held true for the human races: in order to preserve the culturebuilding abilities of the Aryan race the purity of its blood must be preserved. Racial mixture and blood poisoning must be prevented through inbreeding, for "blood mixture and the resultant drop in the racial level is the sole cause of the dying out of old cultures" (MK 296).

30. On the Nazi rejection of Darwin see George Mosse, The Crisis of the German Ideology (New York: Grosset and Dunlap, 1964), p. 103; George Mosse, Toward the Final Solution (Madison: University of Wisconsin Press, 1985), pp. 72-73. Houston Stewart Chamberlain rejected Darwin's theory precisely because "one cannot . . . speak of progression forwards or backwards, but only of motion." See Foundations of the Nineteenth Century, trans. J. Lees (New York: Fertig, 1968), 2: 215. 
All great cultures of the past perished only because the originally creative race died out from blood poisoning. The ultimate cause of such a decline was their forgetting . . . that to preserve a certain culture the man who creates it must be preserved (MK 289).

Far from being a law of natural selection this is in fact a law of artificial selection. ${ }^{31}$ It is precisely natural, uncontrolled breeding which was destroying the Aryan race. The degenerative motion of racial mixture must be prevented by enforcing the higher "racial laws." ${ }^{32}$

Hitler believed that the success of the Jews in "enslaving" other races resulted from their strict obedience to the law of racial preservation. The Jew "practices the severest segregation of his race" and thus keeps his blood pure (MK 315,306,312,316). And at first the Aryan did the same, refusing to mix with other races and thus triumphing over and enslaving culturally inferior peoples.

In the end, however, the conquerors transgress against the principle of blood purity, to which they had first adhered; they begin to mix with the subjugated inhabitants and thus end their own existence; for the fall of man in paradise has always been followed by his expulsion (MK 292).

The Aryan began to lose his racial purity, and this was followed by the eclipse of his creative abilities and the loss of mastery over the inferior peoples with whom he now mixed. The breed was becoming bastardized, and "with their lack of blood unity they also lack unity of will-power and determination to live" (MK 400, 338). With the increasing corruption of his blood the Aryan lost his racial

31. Hans-Guenther Zmarzlik noted that Social Darwinism arose as "a will to assume responsibility for the future because men had lost confidence in a selfevident and automatic progress"; "it was necessary to complement natural selection by a socially guided selection, for otherwise a . . . qualitative deterioration of the human substance was inevitable." See "Social Darwinism in Germany" in Republic to Reich, ed. H. Holborn (New York: Pantheon, 1972), pp. 443-44.

32. Etymologically and biologically Arendt would appear to be right that "racism is the belief that there is a motion inherent in the very idea of race" (Origins, p. 469), but George Mosse argues that "The consciousness of change, of the new speed of time, of the possible loss of control over one's life, were basic issues to which racism addressed itself. Through its appeal to history and nature it attempted to make time stand still, to provide men and women . . . with a piece of eternity that would give them support." For the racist, race is the fixed point that does not depend on the will for its existence - when everything else is taken from him the racist still has his blood and his white skin. See Mosse, Nationalism and Sexuality (New York: Fertig, 1985), p. 150. 
awareness and therefore needed the leadership of the race conscious National Socialists to restore his health and purity.

Hitler claimed that it was the Jews who were ultimately responsible for the degeneration of the Aryan. They sought to entice the German into corrupting his blood because they knew the value of racial purity and could easily dominate and enslave those who had weakened themselves through miscegenation. National Socialism therefore had the twofold task of restoring the health and racial purity of the Aryan and removing the pest which had caused the sickness.

What is more, Hitler claimed that the law of nature commanded precisely the preservation of the racial foundation (rassische Grundlage) of the German people. Hitler understood himself to be tied back to the original foundation of his race and to be engaged in a refounding and restoration of that which had been neglected in the last centuries. Only a return to the racial foundations of the Volk could save it from destruction and enslavement by the Jew.

Indeed, Hitler was obsessed by the need for "foundations," and that image is used repeatedly throughout Mein Kampf. Far from desiring to set the world in motion, Hitler craved stability and solid foundations, "a bulwark against approaching chaos." He bemoaned the fact that "Nothing is anchored any longer. Nothing is rooted within us any longer. Everything is superficial, flies away from us. The thinking of our people is becoming restless and hasty. All of life is being torn asunder." ${ }^{33} \mathrm{He}$ clearly was affected deeply by his traumatic experience in Vienna as a young man and the "uncertainty of earning my daily bread" (MK 25). As a petty bourgeois threatened with proletarianization, Hitler acknowledged "the fear of a social group, which has but recently raised itself above the level of the manual worker, that it will sink back into the old despised class" (MK 23). Only "the creation of better foundations for our development" could allay this fear of falling and also prevent the complete "degeneration" of the proletariat through economic insecurity and unhealthy urban conditions (MK 29). Hitler therefore claimed to have spent his youth "engaged in molding a general platform" and developing "unswerving firmness" in his views (MK 66). Gradually "there took shape within me a world picture and a Weltanschauung which became the granite foundation of all my acts" (MK 22, 125, 155). On the basis of this intellectual foundation-

33. Quoted in Fest, Hitler, pp. 104, 207. 
a knowledge of the eternal laws of nature - he set out to found a party which could save his people, and Hitler solemnly declared in Mein Kampf that "I myself knew that I should some day become an architect" (MK 20, 35). ${ }^{34}$

The goal of National Socialism was to halt the decay of the Aryan people by returning to and preserving its racial foundation. Blood mixture had eroded that foundation and resulted in the defeat and decline of the Volk.

As long as peoples do not recognize and give heed to the importance of their racial foundation, they are like men who would like to teach poodles the qualities of greyhounds, failing to realize that the speed of the greyhound like the docility of the poodle are not learned, but are qualities inherent in the race (MK 338).

The Aryan is the "culture-founding" race: "from him originate the foundations and walls of all human creation"; "he provides the mightiest building stones and plans for all human progress" (MK 290). But by mixing his blood with inferior peoples the Aryan has sinned against his ancestors, who are alive in racially pure blood. To save himself the Aryan must return to his beginnings, to his original racial constitution. The task of National Socialism was to remind the Volk that it was already constituted as a race. Individuals may not do as they please but must preserve their foundations or perish; they must subordinate their will to the higher law of the beginning, for "there is no freedom to sin at the cost of posterity and hence of the race" (MK 254).

For Hitler the absolute was not a law of motion but the racial foundation of a people. To progress a people must remain tied back to its racial constitution and preserve it pure. Far from abolishing its moorings, Hitler spoke of "a single long development in which every generation contributed and fitted its stone." "A really beneficial renascence of humanity will always have to continue where the last good foundation stops." In the tradition of republican thought he declared that "the meaning and purpose of revolutions is not to tear down the whole building, but to remove what is bad or unsuitable and to continue building on the sound spot that has been laid

34. Hitler even used the image of foundation when it was completely inappropriate. For instance: "With the formation of a parliamentary representative body . . . the cornerstone had been laid for the end of German domination of the monarchy" (MK 74). 
bare" (MK 261). Above all this required purging the Jew from the social body of the Aryan because "the Jew destroys the racial foundations of our existence and thus destroys our people for all time" (MK 565).

It is true that Hitler spoke of "the work of higher breeding," the development of a superior man, but this did not mean that the Nazis wished to fabricate a totally new man or race. Superior beings could only be raised on the Aryan foundation. The blood must be purified, and this required not a goalless forward movement but a return to the foundation laid in the past. The racial tradition which had lapsed had to be restored by cleansing the blood of the ancestors. "We must once and for all time create the politically and biologically eternally valid foundations of a German Europe." 35

\section{III}

Despite his republican language, however, Hitler's concept of "racial foundation" was unprecedented. At first glance his desire to return to the racial foundations of the Aryan people may seem to repeat a basic precept of the republican tradition of political thought, expressed for instance by Machiavelli in the Discourses:

And those are the best-constituted bodies, and have the longest existence, which possess the intrinsic means of frequently renewing themselves. . . . And it is a truth clearer than light that, without such renovation, these bodies cannot continue to exist; and the means of renewing them is to bring them back to their original principles. ${ }^{36}$

Hitler might appear to be a kind of Machiavellian prince bringing his people back to its beginnings, but we should note that the racial foundation Hitler claimed to restore was not a product of action. At Rome succeeding generations were tied back to the original act of foundation and constitution-making, which was deemed the authoritative source of all political wisdom. The racial foundation of the Aryan people, however, was not an act. No

35. Quoted in Rauschning, Voice of Destruction, p. 39. Fest notes that the goal of fascism was "to reverse historical development and to return once more to the starting point, to those better, more nature-oriented, harmonious times before the human race began to go astray." See Fest, Hitler, p. 104.

36. Machiavelli, The Prince and The Discourses, trans. M. Lerner (New York: Modern Library, 1950), p. 397 (Bk. 3. chap. 1). 
discrete individual acted to found the Aryan race or to insert himself into history through word or deed. The National Socialists reverenced no Romulus or Aeneas who was said to have founded the race and to have given it laws and institutions. Arendt is right that races are based on "a physical fact" and not "a historical deed." Races are purely natural creations; they arose gradually and unconsciously in the course of evolution. While it may be possible to speak of a genetic foundation of a race, no one chose to found it and interrupt the cyclical flow of nature. Hitler's project, then, turns out to be quite different from the Roman or republican model.

This explains why no principle of authority (auctoritas) arose out of the National Socialist experience. For the Romans the act of foundation became the authoritative principle of the body politic, that which linked them back to the traditions of the ancestors with religious bonds. All change and amendment of the laws required the sanction of the authority of the ancestors to become valid, and a special institution (the Senate) was established to preserve the memory of the ancestors and their authoritative deeds ${ }^{38}$ But unlike Leninism - which did recreate authority by sanctifying the beginning which Marx had made-auctoritas did not suffuse National Socialist politics. This was because the Nazis did not in fact have any founding deeds or ancestors whose memory had to be preserved. The racial "founders" of the Aryan people were completely anonymous because they had never acted or shown themselves in a public space. Nor did the Nazis establish an authoritative institution to incarnate the founders. In the Leninist movement this role was filled by the Party, which preserved the purity of the Founder's principles, but the NSDAP did not fulfill an analogous function in the Nazi movement. The NSDAP never occupied the central position in the Nazi regime that the Senate did in the Roman constitution, or that the Party did in the Soviet system of power, in part because it had no ancestors or authoritative principles to preserve. ${ }^{39}$ Its Weltanschauung, which was quite diffuse, was not the inherited wisdom of a founder. While there had been talk

37. Arendt, Origins, pp. 163, 169, 192. Hitler spoke favorably of Frederick the Great and Bismarck, but these men were not described as founders and forebears.

38. Arendt, "What Is Authority?" pp. 120-24.

39. Mayer, "Hannah Arendt, Leninism, and the Disappearance of Authority." 
in the early years of establishing a Party "senate" to provide counsel to the leader, nothing came of the plan and Hitler increasingly distanced himself from the NSDAP as his own power grew.

While the racial foundation of the Aryan people had emerged naturally, the National Socialists believed that they could not rely on nature to restore it because the will to racial preservation had vanished. To refound the race, however, Hitler turned not to action but to fabrication. The image of a sick and poisoned race which he constantly painted required a founder-doctor to cure it, and as Arendt noted, the physician is like the craftsman who uses technical knowledge and violence to produce a result or object (in this case a healthy body). ${ }^{40}$ The image of the renovator or founder as a doctor is a common one, but unlike Lycurgus, who also described himself as a "wise physician," Hitler's treatment did not consist of lawgiving or constitution-making. What is striking about Hitler's understanding of foundation is that it was not concerned with the creation of institutions or laws. Speaking of the future National Socialist regime, Hitler claimed that "the question of the outward shaping of this state . . . is not of basic importance, but is determined only by questions of practical expediency" (MK 346). National Socialism viewed the state as "only a means to an end and construes its end as the preservation of the racial existence of man" (MK 383). The constitution of the state and its laws were not considered the end-product of fabrication but the means or tools to a higher end, the fabrication of the race. Thus Hitler could declare that

The movement . . . sees its task, not in the restoration of a definite state form and in the struggle against another, but in the creation of those basic foundations without which neither republic nor monarchy can endure for any length of time (MK 346).

The architect-founder neither abrogated the old Weimar constitution nor gave the German people a new one. While Nazi ideology tried to develop a theory of the Führerstaat, in practice the regime was pieced together on an ad-hoc basis and was indeed a chaotic "polyarchy." ${ }^{41}$

40. Arendt, "What Is Authority?" p. 111.

41. On the polyarchal character of the Nazi regime see Martin Broszat, The Hitler-State, trans. J. Hiden (New York: Longman, 1981). 
"To form a Volk is a mightier achievement than to erect a state. States come and states pass, but peoples are created for eternity. ${ }^{\$ 42}$ By seeking to found a people directly, and not through the foundation of a state, National Socialism appears to have carried to an extreme a tendency of modern revolutionary movements. In On Revolution Arendt noted that "from the later stages of the French Revolution up to the revolutions of our own time it appeared to revolutionary men more important to change the fabric of society . . . than to change the structure of the political realm. ${ }^{n 43}$ Constitution-making ceased to be the primary concern of revolutionary founders as attention turned to the solution of the "social question." This held true for National Socialism as well, but for the Nazis the social question was not economic but racial ("the Jewish question"). The founder had to restore the racial purity of his people and purge those poisons which had corrupted its blood. The Second Reich, seemingly stable and well-founded, had collapsed because it had "heedlessly ignor[ed] the question of the preservation of the racial foundations of our nation . . . the sole right which gives life in this world" (MK 327). The founder must not bother himself with mere constitutional questions but must act directly upon the body of the people and fabricate a pure race. Like the doctor performing radical surgery, the founder must use violence and "brutal determination in breaking down incurable tumors" (MK 29). But the founder must also fabricate in the sense that the animal breeder produces a pure stock, "so that in addition to breeding dogs, horses, and cats, they [the German people] will have mercy on their own blood" (MK 646).

"My task is more difficult than Bismarck's or any other German's. I must first create the nation before even beginning to tackle the national tasks before us." ${ }^{\text {44 }}$ National Socialism, I believe, was the clearest attempt to substitute making for acting and to found a people in the literal sense of fabricating it. This was done, however, not to set the world in motion or to create a totally new people, but to revive an imaginary past and to flee the instability inherent in the human condition. By fabricating or refounding the Aryan 939.

42. The Speeches of Adolf Hitler, trans. N. Baynes (New York: Fertig, 1969), 1:

43. Arendt, On Revolution, p. 25. I am suggesting that National Socialism is better explained by Arendt's argument in On Revolution, although Nazism is not mentioned in that work.

44. Quoted in Rauschning, Voice of Destruction, p. 17. 
race Hitler hoped to escape the uncertainty inherent in action, the ability to give birth to something new. Action, Arendt maintained, "corresponds to the human condition of plurality, to the fact that men, not Man, live on the earth and inhabit the world." But she added that "the calamities of action all arise from the human condition of plurality. ${ }^{" 45}$ National Socialism made war on human plurality in order to abolish the uncertainty inherent in it and prevent "the spontaneous beginning of something new," a mixture of the "races" and the resulting "racial chaos. ${ }^{" 46}$ In a sense natality itself was the enemy of National Socialism; it was threatened above all by the movement and diversification inherent in natality, and tried to use genocide and "the iron band of terror" against it.

Unlike the foundings of Aeneas and Romulus, which resulted in a reconciliation of different peoples (Trojans and Latins, Romans and Sabines) under common institutions, Hitler founded in order to reduce the plurality of the human condition to undifferentiated unity and thus eliminate the source of change and motion. Like Plato, he wanted the community to reproduce the sheer oneness of the individual. Arendt is right that National Socialism attacked "the very source of freedom which is given with the fact of the birth of man and resides in his capacity to make a new beginning," but this was done not because action "slowed down" the movement of history but precisely because it hastened it. ${ }^{47}$ National Socialism suffered not from a "perpetual-motion mania" or an urge for goalless forward movement, but rather from the desire for too much stability.$^{48}$ The quest for too sturdy a foundation, not its absence, was the cause of the German catastrophe.

45. Arendt, Human Condition, pp. 7, 220.

46. The attack on plurality is emphasized in Arendt, Eichmann in Jerusalem (New York: Penguin, 1977), "Epilogue.”

47. Arendt, Origins, p. 466.

48. To be sure, the Nazi regime was internally dynamic, but its increasing radicalism after 1937 was directed towards reviving the racial foundation as quickly as possible since Hitler believed that he had little time to achieve his goal. The dynamism was a product of the hectic attempt to fabricate a people in just a few years. Furthermore, it is true that Nazism was externally expansive, but as Hitler noted, "at all times the surest foundation for the existence of a people has been its own soil." Blood and soil were the two foundation-stones of the Aryan people, but space does not permit me to discuss the latter here. See Hitler's Secret Book, trans. S. Attanasio (New York: Grove, 1961), p. 14. 